\title{
PENGARUH GOOD CORPORATE GOVERNANCE DAN UKURAN PERUSAHAAN TERHADAP NILAI PERUSAHAAN (Studi Empiris pada Perusahaan Property and Real Estate Tahun 2016-2018)
}

\section{THE EFFECT OF GOOD CORPORATE GOVERNANCE AND ITS SIZE ON CORPORATE VALUE} (Empirical Study of Property and Real Estate Companies in 2016-2018)

\author{
Nurma Yuni Hafizah'1 \\ 1 Universitas Islam Batik Surakarta - Surakarta \\ Email : Nurmayunihafizah11@gmail.com
}

\begin{abstract}
ABSTRAK
Penelitian ini memiliki tujuan untuk mengetahui pengaruh Kepemilikan Institusional, Ukuran Dewan Komisaris, Kepemilikan Manajerial, Komisaris Independen, Komite Audit, Ukuran Perusahaan terhadap Nilai Perusahaan. Populasi pada penelitian ini adalah Perusahaan sub sektor Property and Real Estate tahun 2016-2018 yang berjumlah 154 perusahaan. Sampel dipilih dari metode purposive sampling dan mendapatkan sample 141 perusahaan dari beberapa kriteria. Sumber data adalah data sekunder dari website (www.idx.co.id). Riset ini menggunakan analisis regresi linear berganda dengan bantuan program SPSS versi 20. Hasil dari riset ini menunjukan Kepemilikan Institusional, Ukuran Dewan Komisaris, Kepemilikan Manajerial, Komisaris Independen, Komite Audit, Ukuran Perusahaan tidak berpengaruh terhadap Nilai Perusahaan.

Kata Kunci: good corporate governance, ukuran perusahaan, nilai perusahaan

ABSTRACT

This study aims to determine the effect of Institutional Ownership, Board of Commissioners Size, Managerial Ownership, Independent Commissioners, Audit Committee, Company Size on Company Value. The population in this study is the company Property and Real Estate subsector in 2016-2018, amounting to 154 companies. The sample was selected from the purposive sampling method and obtained a sample of 141 companies from several criteria. The data source is secondary data from the website (www.idx.co.id). This research uses multiple linear regression analysis with the help of SPSS version 20. The results of this research show Institutional Ownership, Board of Commissioners' Size, Managerial Ownership, Independent Commissioners, Audit Committee, Company Size has no effect on Company Value.
\end{abstract}

Keywords: good corporate governance, company size, company value 


\section{PENDAHULUAN}

(Belia Dinar, 2017) menyatakan Dewan Komisaris Independen tidak berpengaruh signifikan terhadap nilai perusahaan. Berbeda Pendapat dengan (TriyaKSafitri,02018) menyatakan bahwa Dewan Komisaris Independen berpengaruh signifikan terhadap nilai perusahaan.

(MM.Gosal, 2018) menyatakan Komite Audit tidak memiliki pengaruh terhadap nilai perusahaan. Tetapi berbeda dengan pendapat (Mudrikah, 2017) menyatakan bahwa Komite Audit berpengaruh positif terhadap nilai perusahaan, sependapat dengan (Triya Safitri, 2018) bahwa Komite Audit berpengaruh terhadap nilai perusahaan.

(Belia Dinar, 2017) dan (MM.Gosal, 2018) mengungkapkan Kepemilikan manajerial tidak berpengaruh terhadap nilai perusahaan. (Mudrikah, 2017) berpendapat berbeda bahwa kepemilikan manajerial berpengaruh positif terhadap nilai perusahaan, begitu juga dengan pendapat (Triya Safitri,u2018).

Berdasarkan uraian pendahuluan diatas, maka perumusan masalah dalam penelitian ini adalah, antara lain 1) Apakah Kepemilikan Institusional berpengaruh terhadap nilai perusahaan. 2) Apakah Ukuran Dewan Komisaris berpengaruh terhadap nilai perusahaan. 3) Apakah Kepemilikan Manajerial berpengaruh terhadap nilai perusahaan. 4) Apakah Komisaris Independen berpengaruh terhadap nilai perusahaan. 5) Apakah Komite Audit berpengaruh terhadap nilai perusahaan. 6) Apakah Ukuran Perusahaan berpengaruh terhadap nilai perusahaan.

\section{LANDASAN TEORI}

\section{Teori Keagenan}

Prasetyantoko (2008) dalam teori agensi ini menyangkut kebijakan keuangan perusahaan, terutama terhadap dua pilihan apakah akan menggunakan utang patau modal sendiri (equity) untuk membiayai kegiatan usaha. Konflik agency dapat dipengaruhi oleh Kepemilikan Manajerial dan Kepemilikan Institusional.

\section{Nilai Perusahaan}

Hasnawati (2005) nilai perusahaan bisa ditentukan dengan tingkat kemakmuran pemegang saham, yang diukur dengan harga saham di pasar modal dan pertumbuhan pasar. Harga saham telah memenuhi syarat efisiensi secara informasional. Tetapi, harga saham di pasar modal biasanya berbentuk dengan adanya kesepakatan bantar penawar dan permintaan investor, sehingga harga saham merupakan fair frace dapat menjadi acuan nilai perusahaan.

\section{Kepemilikan Institutional}

Jensen dan Meckling (1976) kepemilikan institusional memiliki peran yang sangat penting dalam meminimalkan agency konflik yang terjadi antara manajer (agen) dan pemegang saham (principal). Rahmi and arnovinsah (2013) menyatakan bahwa dengan tingkat yang lebih efektif monitor diharapkan akan meningkatkan nilai perusahaan dimasa depan.

\section{Ukuran Dewan Komisaris}

Jumlah anggota dewan komisaris sangat mempengaruhi Good Governance. Akhtaruddin et al. (2009),Semakin besar ukuran dewan komisaris, maka pengalaman akan bertambah, sehingga informasi yang didapat oleh manajemen akan lebih luas. 


\section{Kepemilikan Manajerial}

Menurut Machmud dan Djakman (2008) Kepemilikan saham manajerial yaitu tingkat kepemilikan pihak manajemen yang secara aktif dalam pengambilan keputusan. Jensen dan Mecking (1976) pada Herawaty (2008) mengemukakan kepemilikan manajerial berhasil menjadi mekanisme untuk mengurangi masalah keagenan dari manajer dengan menyelaraskan kepentingan-kepentingan manajer dengan pemegang saham.

\section{Komisaris Independen}

Menurut UU PT Nomor 40 Tahun 2007 ayat 6 dalam Agoes dan Ardana (2014:108) dewan komisaris independen yang bertugas melakukan pengawasan secara umum sesuai anggaran dasar dan dapat memberikan masukan kepada dewan direksi, tetapi dewan komisaris tidak boleh ikut campur dalam pengambilan keputusan operasional.

\section{Komite Audit}

Komite audit bertugas mengawasi dan mengelola pelaporan sistem penendalian internal dan penerapan prinsip akuntansi secara keseluruhan (Shabibah, 2017).

\section{Ukuran Perusahaan}

Menurut Riyanto (2008:313) ukuran perusahaan adalah besar kecilnya perusahaan dilihat dari nilai equity dan nilai penjualan.

\section{Pengembangan Hipotesis}

\section{Kepemilikan Institusional terhadap Nilai Perusahaan}

Rahmi and arnovinsah (2013) menyatakan bahwa dengan tingkat yang lebih efektif monitor diharapkan dapat meningkatkan nilai perusahaan dimasa depan. Sukirni (2012) serta Widyaningsih (2018) menyatakan bahwa kepemilikan institusional memiliki efek positif pada nilai perusahaan. Berdasarkan uraian tersebut, hipotesis kedua dapat disimpulkan sebagai berikut:

H1 : Kepemilikan institusional berpengaruh terhadap nilai perusahaan

\section{Ukuran Dewan Komisaris terhadap Nilai Perusahaan}

Menurut Widyaningsih (2018) komisaris independen dapat mengawasi dan memberikan nasihat kepada direksi obyektif. Dengan pengawasan tersebut, itu akan mempengaruhi kinerja direksi sehingga mereka dapat meningkatkan nilai perusahaan. Beberapa hasil penelitian dari Raharja (2014), Onasis (2016), Arifin (2017), dan Widyaningsih (2018) menyatakan bahwa dewan komisaris memiliki efek positif pada nilai perusahaan.

\section{H2 : Ukuran Dewan Komisaris berpengaruh positif terhadap nilai perusahaan}

\section{Kepemilikan Manajerial terhadap Nilai Perusahaan}

Mudrikah, Roni Malavia Mardani, dan Budi Wahono (2017) Berdasarkan hasil penelitian nya dapat disimpulkan bahwa secara parsial kepemilikan manajerial berpengaruh negatif signifikan terhadap nilai perusahaan.

H3 : kepemilikan manajerial berpengaruh negatif signifikan terhadap nilai perusahaan.

\section{Komisaris Independen terhadap Nilai Perusahaan}

Siallagan dan Machfoedz (2006) yang menunjukan bahwa dewan komisaris independen berpengaruh positif terhadap nilai perusahaan. maka dapat dirumuskan dari kedua hipotesis tersebut, bahwa : 
H4 : Dewan Komisaris Independen berpengaruh positif terhadap nilaia perusahaan

\section{Komite Audit terhadap Nilai Perusahaan}

Menurut Tambunan, Saifi dan Hidayat (2017) dan Soedaryono dan Riduifana (2013) yang menemukan bahwa komite audit memiliki negatif dan pengaruh signifikan pada nilai perusahaan.

H5 : Komite Audit berpengaruh negatif signifikan terhadap nilai perusahaan

\section{Ukuran Perusahaan terhadap Nilai Perusahaan}

Nuraina (2012),Rahma (2014),Rahmawati et al. (2015), dan Pratiwi (2017) menyimpulkan bahwa ukuran firm memiliki positif dalam memengaruhi nilai perusahaan. Artinya, semakin besar ukuran firm akan meningkatkan nilai perusahaan. Hal ini karena ukuran firm dihargai oleh total aset perusahaan untuk mengoperasikan perusahaan.

H6 : Ukuran perusahaan berpengaruh terhadap nilai perusahaan

\section{METODOLOGI PENELITIAN}

\section{Jenis dan Sumber Data Penelitian}

Jenis data yang digunakan dalam penelitian ini adalah data sekunder, Data sekunder berupa laporan keuangan tahunan. Data yang diperoleh dari perusahaan sub sektor Property Real Estate yang terdaftar di Bursa Efek Indonesia yang berupa angka-angka sehingga dapat diolah dan dianalisis menggunakan metode regresi sehingga dapat diketahui hasilnya.Populasi yang digunakan dalam penelitian ini adalah semua Perusahaan sub sektor Property and Real Estate tahun 2016-2018. Pengambilan sampel dilakukan dengan metode purposive sampling. Jumlah populasi 154 yang memenuhi kriteria sebanyak 141 perusahaan, maka data penelitian 47 x 3 tahun yaitu 141 data.

\section{Metode Analisis dan Hipotesisi Penelitian}

Pengujian pertama dengan uji statistik deskriptif, Kemudian pengujian asumsi klasik sebagai salah satu syarat untuk bisa menggunakan persamaan regresi berganda adalah terpenuhinya uji asumsi klasik. Empat uji asumsi klasik dalam penelitian ini meliputi normalitas, asumsi heteroskedastisitas, autokorelasi dan multikolinearitas. Penjelasan masing-masing pengujian asumsi klasik akan diuraikan seperti di bawah ini. Lanjutan pengujian untuk metode analisis yang digunakan untuk menguji pengaruh variabel bebas terhadap terikat dengan Uji T, Uji F dan Uji Determinasi.

\section{Variabel dan Pengukuran}

\section{Dependen}

Nilai Perusahaan

Nilai perusahan dihitung dengan menggunakan model Tobin's Q. Variabel ini telah digunakan oleh Suranta dan Midiastuty (2003) :

\begin{tabular}{ll|}
\hline$Q=$ & $\begin{array}{ll}(E M V)+D \\
\end{array}$ \\
\hline$Q$ & : Nilai Perusahaan \\
EMV & : Nilai pasar ekuitas (EMV = closing price $x$ jumlah saham yang beredar) \\
EBV & : Nilai buku dari total ekuitas (EBV $=$ total aset - total kewajiban) \\
$D$ & : Nilai buku dari total hutang
\end{tabular}




\section{Independen}

\section{Kepemilikan Institusional}

Kepemilikan institusional memiliki peranan yang penting dalam meminimalisasi konflik keagenan yang terjadi diantara pemegang saham dengan manajer. Kepemilikan Institusional dapat diukur dengan (Sari dan Riduwan, 2010):

$$
\text { INS }=\frac{\text { Jumlah Saham Institusi }}{\text { Jumlah Saham Beredar }}
$$

\section{Ukuran Dewan Komisaris}

Semakin besar jumlah anggota dewan komisaris, maka akan semakin mudah untuk mengendalikan CEO dan monitor yang dilakukan akan semakin efektif. Jadi menurut Sembiring (2005) pengukuran ukuran dewan komisaris menggunakan jumlah anggota dewan komisaris.

\section{Ukuran Dewan Komisaris $=$ Jumlah Anggota dewan Komisaris}

\section{Kepemilikan Manajerial}

Nuraninun, Juwita, dan Krisnawati (2012) diukur dengan menghitung presentase (\%) jumlah saham yang dimiliki oleh pihak manajemen dibagi dengan total jumlah saham yang beredar. Rumus kepemilikan manajerial sebagai nmberikut:

\begin{tabular}{|ll|}
\hline Kepemilikan Manajerial $=$ & $\begin{array}{l}\text { Jumlah Saham Manajemen } \\
\end{array}$ \\
Jumlah Saham yang Beredar & \\
\hline
\end{tabular}

\section{Dewan Komisaris Independen}

Dewan komisaris independen merupakan anggta dewan komisaris yang tidak ada hubungannya dengan kepemilikan saham atau hubungan keluarga, hubungan keuangan yang dapat memengaruhi kemampuan untuk melakukan tindakan independen. Pengukurannya (Sari dan Riduwan, 2010):

$$
\text { PDKI }=\frac{\text { Jumlah Komisaris Independen }}{\text { Jumlah Komisaris }}
$$

\section{Komite Audit}

Variabel independen dalam penelitian ini yang ketiga adalah komite audit yang diukur dengan menggunakan rumus:

$$
\text { Komite Audit }=\frac{\text { Jumlah Komite Audit }}{\text { Jumlah Seluruh Komite Audit }}
$$

\section{Ukuran Perusahaan}

Indikator yang digunakan untuk mengukur variabel ini adalah indikator Total Aset menurut Hartono (2015:282), yaitu:

$$
\text { Ukuran Perusahaan }=\text { Total Aset }
$$




\section{HASIL DAN PEMBAHASAN}

Besarnya angka koefisien determinasi adalah 0,075 atau sama dengan 7,5\%. Angka tersebut mengandung arti bahwa variabel Kepemilikan Institusional, Ukuran Dewan Komisaris, Kepemilikan Manajerial, Komisaris Independen, Komite Audit, dan Ukuran Perusahaan secara simultan (bersama-sama) berpengaruh terhadap variabel Nilai Perusahaan sebesar 7,5\%. Sedangkan sisanya $92,5 \%$ dipengaruhi oleh variabel lain di luar persamaan regresi ini atau variabel yang tidak diteliti.

\section{Tabel}

Hasil Pengujian Hipotesis

\begin{tabular}{lrrrr}
\hline \multicolumn{1}{c}{ Variabel } & $\begin{array}{c}\text { Understandardized } \\
\text { Coefficients }\end{array}$ & $\begin{array}{c}\text { Standardized } \\
\text { Coefficients }\end{array}$ & uji t & $\begin{array}{r}\text { Probabilitas } \\
\text { (Sig. A 0,05) }\end{array}$ \\
\hline Constant & $-1,431$ & & 1,322 &, 173 \\
INST (X1) &, 000 &, 095 &, 652 &, 281 \\
UKDEWKOM (X2) &,- 017 &,- 049 &,- 294 &, 817 \\
MANAJERIAL (X3) &,- 021 &,- 040 &,- 279 &, 199 \\
KOMISINDEP (X4) & 1,209 &, 043 &, 247 &, 075 \\
\hline KOMITAUDT (X5) &, 574 &,- 155 & $-1,046$ &, 088 \\
\hline UKPERUSHN (X6) &, 001 &, 145 & 1,006 &, 509 \\
\hline R Square & & & &, 172 \\
Adjusted R Square & & & &, 075 \\
Fhitung & & & & 1,766 \\
Probabilitas & & & &, 008 \\
\hline
\end{tabular}

Hasil uji masing-masing hipotesis (parsial) berdasarkan hasil output spss di atas, dapat diketahui bahwa nilai konstanta sebesar $-1,431$. Dengan nilai tersebut maka dapat diartikan bahwa Harga Saham akan bernilai 1,431 apablia masing-masing variabel Kepemilikan Institusional, Ukuran Dewan Komisaris, Kepemilikan Manajerial, Komisaris Independen, Komite Audit, dan Ukuran Perusahaan bernilai 0. Kepemilikan Institusional mempunyai koefisiensi regresi sebesar ,000 mempunyai arti setiap kenaikan 1 satuan Kepemilikan Institusional dengan asumsi variabel lain tetap maka akan menaikkan harga saham ,000. Ukuran Dewan Komisaris mempunyai koefisiensi regresi sebesar -,017 mempunyai arti setiap kenaikan 1 satuan Ukuran Dewan Komisaris dengan asumsi variabel lain tetap maka akan menaikkan harga saham 0,017. Kepemilikan Manajerial mempunyai koefisiensi regresi sebesar -,021 mempunyai arti setiap kenaikan 1 satuan Kepemilikan Manajerial dengan asumsi variabel lain tetap maka akan menaikkan harga saham 0,021 . Komisaris Independen mempunyai koefisiensi regresi sebesar 1,209 mempunyai arti setiap kenaikan 1 satuan Komisaris Independen dengan asumsi variabel lain tetap maka akan menaikkan harga saham 1,209. Komite Audit mempunyai koefisiensi regresi sebesar ,574 mempunyai arti setiap kenaikan 1 satuan Komite Audit dengan asumsi variabel lain tetap maka akan menaikkan harga saham ,574. Ukuran Perusahaan mempunyai koefisiensi regresi sebesar ,001 mempunyai arti setiap kenaikan 1 satuan Ukuran Perusahaan dengan asumsi variabel lain tetap maka akan menaikkan harga saham ,001.

Berdasarkan hasil output spss di atas menunjukkan bahwa hasil uji variabel hipotesis secara serentak (simultan) diketahui $F_{\text {hitung }}$ sebesar 1,766, dan nilai sig sebesar 0,008. Karena nilai sig $\mathrm{F}$ nya lebih kecil dari $0,05(0,008<0,05)$ maka dapat disimpulkan bahwa Kepemilikan Institusional, Ukuran Dewan Komisaris, Kepemilikan Manajerial, Komisaris Independen, Komite 
Audit, dan Ukuran Perusahaan berpengaruh signifikan terhadap Nilai Perusahaan secara simultan. Dari tabel di atas maka diperoleh model regresi liniear berganda

$$
Y=-1,431+0,000 X_{1}-0,017 X_{2}-0,021 X_{3}+1,209 X_{4}+0,574 X_{5}+0,001 X_{6}+e
$$

\section{REKOMENDASI KEBIJAKAN}

\section{Rekomendasi}

1. Untuk penelitian selanjutnya untuk memperluas sampel penelitian dan memperpanjang peride pengamatan.

2. Di penelitian selanjutnya diharapkan menambah variabel lain.

\section{Kebijakan}

1. Penelitian ini hanya menggunakan perusahaan sub sektor Property and Real Estate dengan peride pengamatan 3 tahun berturut-turut.

2. Nilai Adjusted $\mathrm{R}$ Square hanya sebesar $7,5 \%$ yang berpegaruh, berarti masih banyak variabel yang berpengaruh pada nilai perusahaan. 


\section{DAFTAR PUSTAKA}

Dewi, L. C., \& Nugrahanti, Y. W. (2014). Pengaruh Struktur Kepemilikan Dan Dewan Komisaris Independen. Kinerja , 64-80.

Fransiska, Y., Endang.S, R., \& Purwanto, N. (T.Thn.). Pengaruh Kepemilikan Institusional, Kepemilikan Manajerial, Dan Kebijakan Dividen Terhadap Kebijakan Hutang Pada Perusahaan Manufaktur Yang Terdaftar Di Bursa Efek Indonesia Tahun 2012-2014. Jurnal Riset Mahasiswa Xxxxxxx .

Gosal, M. M., Pangemanan, S., \& Tielung, M. V. (2018). The Influence Of Good Corporate Governance On Firm Value: Empirical Study Of Companies Listed In Idx30 Index Within 2013-2017 Period. Jurnal Emba , 2688-2697.

Indriyani, E. (2017). Pengaruh Ukuran Perusahaan Dan Profitabilitas. Jurnal IImu Akuntansi, 333-348.

Khasanah, A. N. (2018). Pengaruh Rasio Likuiditas, Profitabilitas, Struktut Modal Dan Ukuran Perusahaan Terhadap Nilai Perusahaan Pada Perusahaan Manufaktur Yang Terdaftar Di Bei Tahun 2015-207. Jurnal Penelitiaan Ekonomi Dan Bisnis , 3-47.

Mudrikah, Mardani, R. M., \& Wahono, B. (T.Thn.). Analisis Pengaruh Good Corporate Governance Terhadap Nilai Perusahaan. Jurnal Riset Manajemen .

Nurfaza, B. D., Gustyana, S. T., \& Iradianty, S. A. (2017). Pengaruh Good Corporate Governance Terhadap Nilai Perusahaan. E-Proseeding Of Management, (Hal. 2261-2266).

Rahayu, D. P. (2019). The Effect F Intelectual Capital Disclosure, Corporate Governance, And Firm Size N Firm Value. Kne Social Science , 530-548.

Soedaryono, B., \& Riduifana, D. (2013). Pengaruh Good Corporate Governance. Media Riset Akuntansi, Auditing \& Informasi .

Susilaningrum, C. (2016). Pengaruh Return On Assets, Rasio Likuiditas, Dan Rasio Solvabilitas Terhadap Nilai Perusahaan Dengan Pengungkapan Corporate Social Responsibility (Csr) Sebagai Variabel Moderasi. Jurnal Profita .

Syafitri, T., Nuzula, N. F., \& Nurlaily, F. (2018). Pengaruh Good Corporate Governance Terhadap Nilai. Jurnal Administrasi Bisnis .

Ulum, I., Malik, M., \& Sofyani, H. (2019). Analisis Pengungkapan Modal Intelektual: Perbandingan Antara Universitas Di Indonesia Dan Malaysia. Jurnal Ekonomi Dan Bisnis , 163-182. 